\title{
Fluid Evolution of the Magmatic Hydrothermal Porphyry Copper Deposit Based on Fluid Inclusion and Stable Isotope Studies at Darrehzar, Iran
}

\author{
B. Alizadeh Sevari ${ }^{1}$ and A. Hezarkhani ${ }^{2}$ \\ ${ }^{1}$ Department of Basic Sciences, Payame Noor University, P.O. Box 19395-3697, Tehran, Iran \\ ${ }^{2}$ Department of Mining and Metallurgy Engineering, Amirkabir University of Technology, Tehran, Iran
}

Correspondence should be addressed to B. Alizadeh Sevari; beh.alizadeh@gmail.com

Received 3 August 2013; Accepted 22 September 2013; Published 8 January 2014

Academic Editors: A. C. Riccardi and A. V. Travin

Copyright (C) 2014 B. Alizadeh Sevari and A. Hezarkhani. This is an open access article distributed under the Creative Commons Attribution License, which permits unrestricted use, distribution, and reproduction in any medium, provided the original work is properly cited.

\begin{abstract}
The Darrehzar porphyry Cu-Mo deposit is located in southwestern Iran ( $70 \mathrm{~km}$ southwest of Kerman City). The porphyries occur as Tertiary quartz-monzonite stocks and dikes, ranging in composition from microdiorite to diorite and granodiorite. Hydrothermal alteration and mineralization at Darrehzar are centered on the stock and were broadly synchronous with its emplacement. Early hydrothermal alteration was dominantly potassic and propylitic and was followed by later phyllic and argillic alteration. The hydrothermal system involved both magmatic and meteoric water which were boiled extensively. Copper mineralization was accompanied by both potassic and phyllic alterations. Based on number, nature, and phases number which are available in room temperature, three types of fluid inclusions are typically observed in these veins: (1) vapor rich, (2) liquid rich and (3) multi phase. The primary multiphase inclusions within the quartz crystals were chosen for microthermometric analyses. Early hydrothermal alteration was caused by high-temperature, high-salinity orthomagmatic fluid and produced a potassic assemblage. Phyllic alteration was caused by high-salinity and lower-temperature orthomagmatic fluid. Magmatic and meteoric water mixtures were developed in the peripheral part of the stock and caused propylitic alteration which is attributed to a liquid-rich, lower temperature.
\end{abstract}

\section{Introduction}

Due to their low metal grade and very large volume, porphyry-type deposits are described as disseminated and mineralization is, to a great extent, controlled by fractures and faults.

Porphyry copper deposits are formed where magmatichydrothermal fluids are expelled from a crystallizing magma $[1,2]$ and initiated by injection of oxidized magma saturated with S- and metal-rich, aqueous fluids from cupolas on the tops of the subjacent parental plutons. The sequence of alteration-mineralization is principally a consequence of progressive rock and fluid cooling caused by solidification of the underlying parental plutons and downward propagation of the lithostatic-hydrostatic transition [3]. Cooling, depressurization, and reaction between the fluids and the wall rocks cause metals to precipitate in and around the fractures, forming veins with alteration envelopes. Alteration assemblages and associated mineralization in porphyry ore deposits develop from huge hydrothermal systems dominated by magmatic and meteoric fluids $[4,5]$.

Porphyry $\mathrm{Cu}$ systems host some of the most widely distributed mineralization types at convergent plate boundaries including porphyry deposits centered on intrusions. The systems commonly define linear belts, some many hundreds of kilometers long, as well as occurring less commonly in apparent isolation [3].

Sahand-Bazman volcanic belt in Iran is a part of the collisional Alpine-Himalaya orogenic belt, which extends north-westward from Sahand volcano in Azerbaijan province, to Bazman volcano in southeast Iran, a distance of approximately $1700 \mathrm{~km}$. This belt was formed by subduction of the Arabian plate beneath central Iran during the Alpine orogeny as first identified by Stocklin and Setudenia [6] 
and consists of alkaline and calc-alkaline volcanic rocks and related intrusions (I-type) [7-11].

Darrehzar deposit is located southeast of the Sarcheshmeh porphyry $\mathrm{Cu}$ deposit. Proven reserve of Darrehzar deposit is $>80$ million tons of disseminated sulfide ore, with an average grade of $0.55 \% \mathrm{Cu}$ and approximately $0.005 \% \mathrm{Mb}$ [12].

First studies at Darrehzar were carried out in 1969 by Geologic Survey of Iran, containing detailed geophysical, geochemical, and geological surveys. Next studies were published by Grujicic and Volickovic [13], Maanijou [14], and Ranjbar et al. [15].

In this study, for the first time at Darrehzar area, we will elucidate the hydrothermal history of the Darrehzar porphyry deposit in order to identify the factors controlling copper-molybdenum mineralization. We have conducted a fluid inclusion study and analyzed oxygen and sulfur isotopic compositions of selected minerals. This information has enabled us to determine the conditions under which the deposit formed, reconstruct the fluid evolution, and develop a model which satisfactorily explains the concentration of $\mathrm{Cu}$ mineralization.

\section{Geological Setting}

The Darrehzar porphyry copper deposit is located $\sim 70 \mathrm{~km}$ southwest of Kerman City in the Kerman province of southwestern Iran (Figure 1). The stock is a part of the SahandBazman igneous and metallogenic belt, a deeply eroded Tertiary volcanic field, roughly 100 by $1700 \mathrm{~km}$ in extent, consisting mainly of rhyolite and andesite, with numerous felsic intrusions. Subduction and subsequent continental collision from Paleocene to Oligocene caused extensive alkaline and calc-alkaline volcanic and plutonic igneous activity [16-18].

The Darrehzar porphyries occur as Tertiary quartzmonzonite stocks and dikes, ranging in composition from microdiorite to diorite and granodiorite, intruding into volcanic, volcanic-clastic, and volcanic sedimentary complexes. The volcanic sedimentary complex is the oldest rock with eocene age, covering a large area of Darrehzar.

Andesite and pyroclastic rocks are situated in the peripheral parts of altered rock while microdiorite, diorite, and granodiorite stocks build the central part of alteration zone. In this part, alterations are more intensive, rocks are crushed, and system of fracturing is well developed. Along both sides of Darrehzar rivers remnant, of the river trace are situated and composed of pebbles of andesite and altered rocks, cemented with clay and limonite.

The Darrehzar stock is highly altered, and even in the outermost part of the intrusion it is not possible to find completely fresh rock. Surface weathering has developed Fe-rich lithological units in leached zone and concentrated copper minerals in supergene zone.

\section{Hydrothermal Alteration and Mineralization}

Alteration assemblages and related mineralization in the Darrehzar porphyry copper deposit have been investigated by geological mapping, and detailed mineralogical petrographical and chemical studies of a large number of drill cores and outcrop samples from various parts of the stock have been carried out. Hydrothermal alterations at Darrehzar deposit are very intensive and weathering process changed them even more. The central part of Darrehzar is composed of intensively hydrothermally altered rocks, covering the surface of about $1.8 \mathrm{~km}^{2}$. Altered zone is elongated in eastwest direction, $2.2 \mathrm{~km} \times 1 \mathrm{~km}$ in size. Boundary between the altered and unaltered rocks is sharp and in some parts it is very irregular. At some area altered rocks interfinger with unaltered ones.

Early hydrothermal alteration was dominantly potassic and propylitic and was followed by later phyllic and argillic alterations. The earliest alteration is represented by potassic mineral assemblages developed pervasively and by halos around veins in the deep and central parts of the Darrehzar stock. Potassic alteration is characterized by K-feldspar and secondary biotite. This alteration displays a close spatial association with mineralization. Eastern boreholes reached potassic alteration in shallower depth than western boreholes, indicating the presence of north-south reverse fault and erosion of overall alterations in this area.

The change from potassic to phyllic alteration is gradual and is marked by an increase in the proportion of muscovite. Phyllic alteration is characterized by the replacement of almost all rock-forming silicates by sericite and quartz and overprints the earlier formed potassic alteration. Surface samples of phyllic alteration with gray color have quartz content in rocks and veins and are harder. Quartz veins are surrounded by weak sericitic halos. Vein-hosted pyrite is partially replaced by chalcopyrite. Silicification was synchronous with phyllic alteration and variably affected a large part of the stock and most dikes. In contrast to the transition zone, appreciable $\mathrm{Cu}$ was added to the rock during phyllic alteration.

Because of erosion, propylitic alteration zone especially at eastern area of Darrehzar was rarely detected in borehole samples and only was seen in contact area of porphyry stock with eocene volcanic and volcano-clastic rocks.

Propylitic alteration is represented mainly by chloritization of primary and secondary biotite and groundmass material in rocks peripheral to the central potassic zone. Epidote replaced plagioclase, but this alteration is less pervasive and less intense than chloritization. Minor mineral associated with propylitic alteration are albite, calcite, sericite, anhydrite (gypsum), and pyrite.

The shallow argillic alteration is interpreted to represent a supergene blanket over the deposit and the deeper clay alteration of feldspar may have had the same origin. Rocks with argillic alteration are highly fractured and bleached. Some samples have aggregation of chlorite and clay minerals.

Feldspar is locally altered to clay down to a depth of $300 \mathrm{~m}$, and within $80 \mathrm{~m}$ of the erosional surface the entire rock has been altered to an assemblage of clay minerals. XRD analyses indicate that kaolinite is the dominant clay mineral mixed with rarely montmorillonite and other erosion minerals. This alteration is manifested by advanced replacement of plagioclase and mafic phases by clay minerals. 


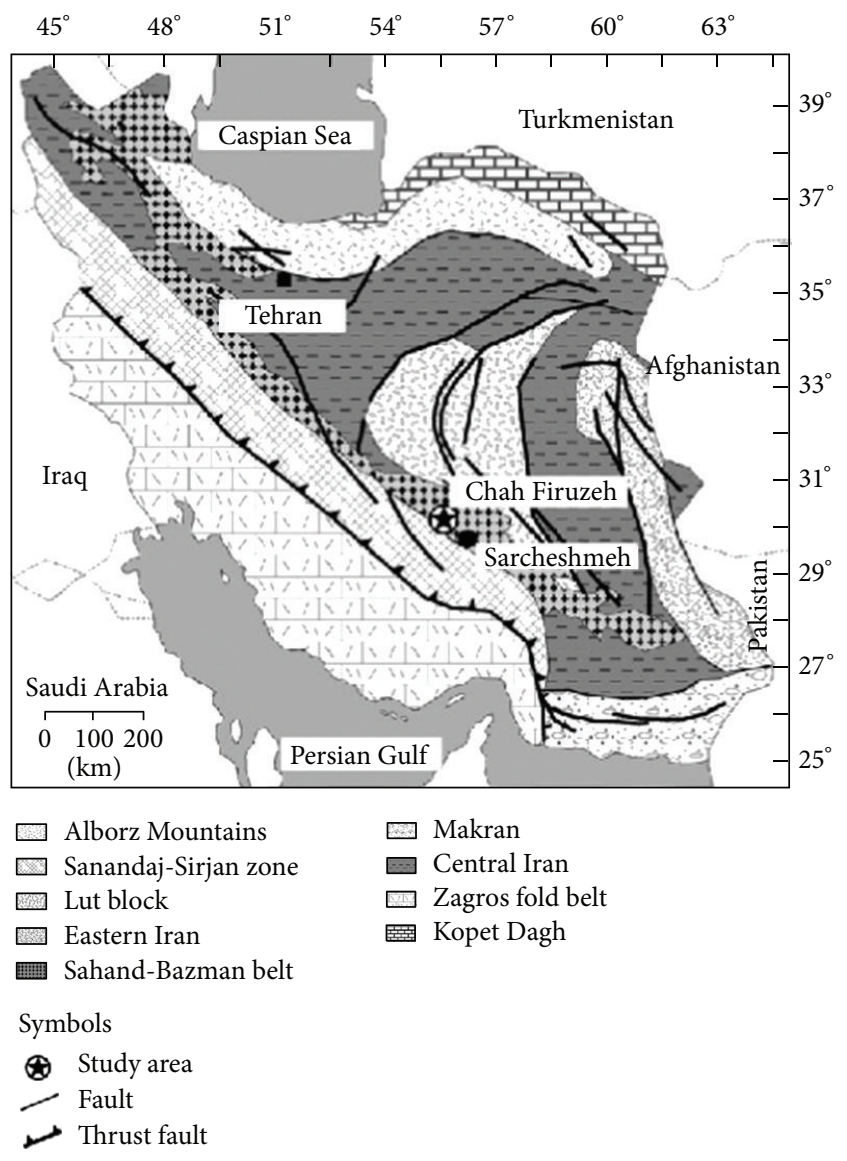

(a)

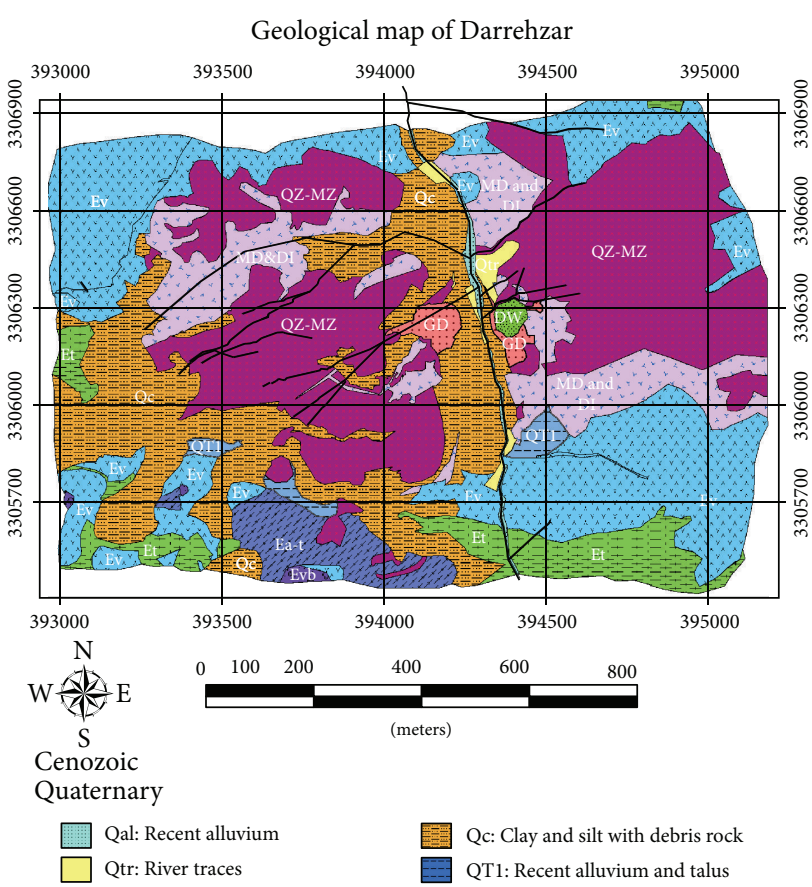

Cenozoic

Oligo-Miocene
Gd: Granodiorite
MD\&DI: Microdiorite and diorite

\section{Cenozoic}

Eocene

Evb: Volcanic breccia
Ev: Andesite and andesite basalt
DW: Dam water

Ea-t: Andesite, andesite basalt, crystal tuff, vitric tuff, vitric lithic tuff, lapilli tuff, and agglomerate

Et: Crystal tuff, vitric tuff, vitric lithic tuff, lapilli tuff, and agglomerate

(b)

FIGURE 1: (a) Geological map of Iran (7 and 20) showing Sahand-Bazman belt: calc-alkaline volcanic and quartz-monzonite and quartz diorite intrusions, hosting $\mathrm{Cu}$-Mo-porphyry-type mineralization and (b) detailed geological map of the Darrehzar area showing the distribution of different sites.

Based on drill cores, hypogene copper mineralization was introduced during potassic and phyllic alteration and exists as disseminations and as veinlets form. During potassic alteration, the copper mineralization consisted of chalcopyrite and bornite; later hypogene copper mineralization consisted mainly of chalcopyrite.

Copper grades and sulphide content increase toward the margins of the central potassic zone, from less than $0.10 \mathrm{wt} \%$ to $0.9 \mathrm{wt} \%$. There is also a positive correlation between silicification and copper mineralization.

At the exposed surface of the deposit, rocks are highly altered and the only mineral which has survived supergene argillization is quartz. Most of the sulfide minerals have been leached, and copper was concentrated in an underlying supergene zone by downward percolating ground waters.

\section{Vein and Veinlet Classification}

The veinlet sequence in porphyry $\mathrm{Cu}$ deposits, first detailed by Gustafson and Hunt [19] and widely studied since [18], is highly distinctive. Based on mineralogy and cross-cutting relationships at Darrehzar area, it is possible to distinguish four main groups of veins representing four episodes of vein formation: (I) quartz + pyrite \pm molybdenite \pm anhydrite \pm k-feldspar \pm chalcopyrite \pm bornite $\pm \mathrm{cu}$ and fe oxidic minerals (peripheral); (II) quartz + chalcopyrite + pyrite + molybdenite; (III) quartz + pyrite \pm calcite \pm chalcopyrite \pm anhydrite (gypsum); (IV) quartz or calcite, gypsum or \pm pyrite.

\section{Fluid Inclusions Studies}

Fluid inclusions from sulfide-bearing quartz veins obtained from drill cores were studied (Figure 2). The samples of fluid inclusions are abundant in quartz of all vein types, and range in diameter from $1 \mu \mathrm{m}$ up to $15 \mu \mathrm{m}$. The majority of inclusions examined during this study had diameters of 4$12 \mu \mathrm{m}$. Only fluid inclusions within the quartz crystals in quartz-sulfide and quartz-molybdenite veinlets were chosen for microthermometric studies. Most of the observations 


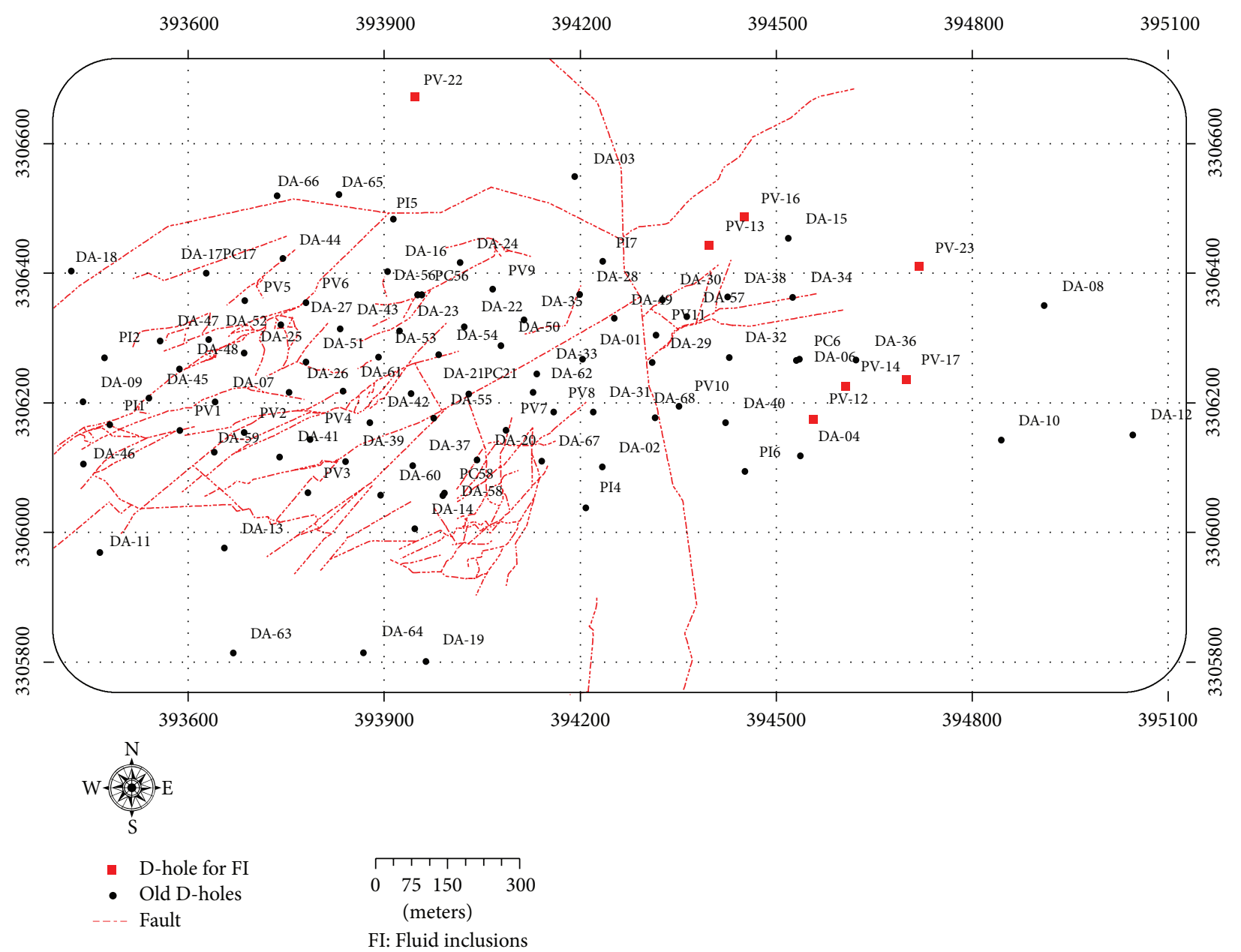

FIgURE 2: Location map of drill holes (red circles refer to locations of drill holes that were sampled).

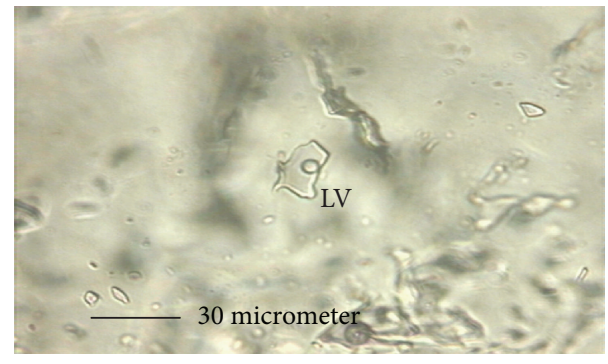

(a)

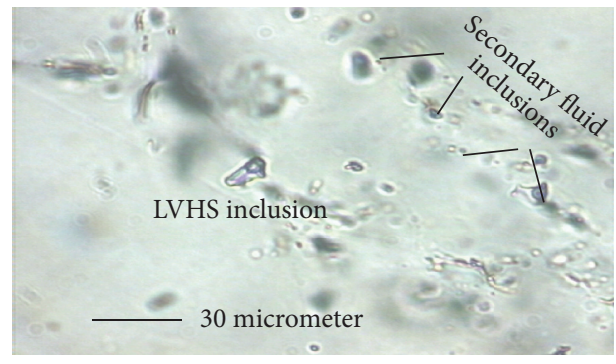

(b)

FIGURE 3: Photomicrographs of different inclusion types within mineralized quartz vein.

were restricted to fluid inclusions in coarse-grained quartz of early mineralized veins.

Fluid inclusions were classified into three main types based on the number, nature, and proportion of phases at room temperature. The following types of fluid inclusions have been identified (Figure 3). (1) Liquid vapor (LV) inclusions consist of liquid + vapor \pm solid phases with the liquid phase volumetrically dominant. These fluid inclusions are common in all mineralized quartz veins and are abundant in Groups II and III veins. (2) Vapor liquid (VL) inclusions also contain vapor + liquid \pm solid phases. These inclusions mainly homogenize to vapor, and rarely to liquid, or by Critical Homogenization. (3) Liquid vapor halite solid (LVHS) inclusions are multiphase and consist of liquid + vapor + halite + other solids. Based on the number and type of the solids, this type of inclusions is further classified into three 


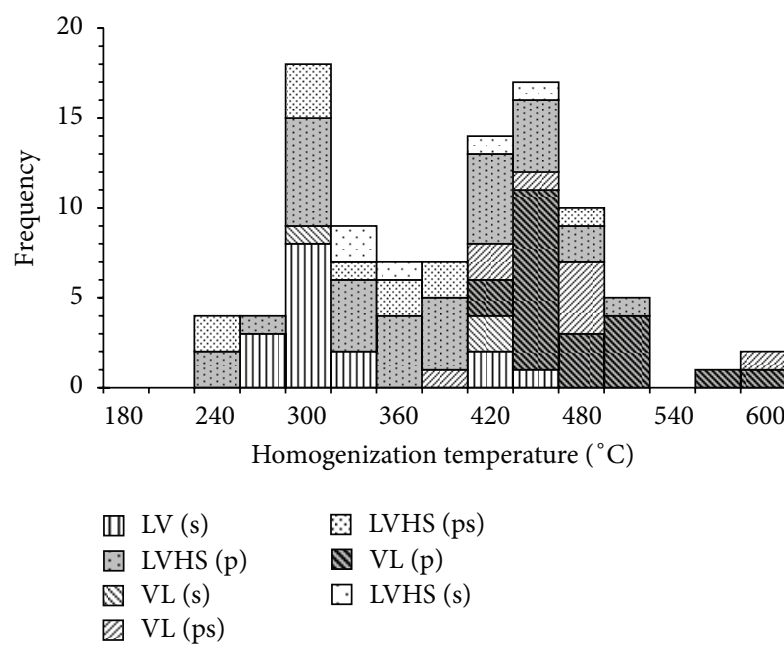

(a) Group I

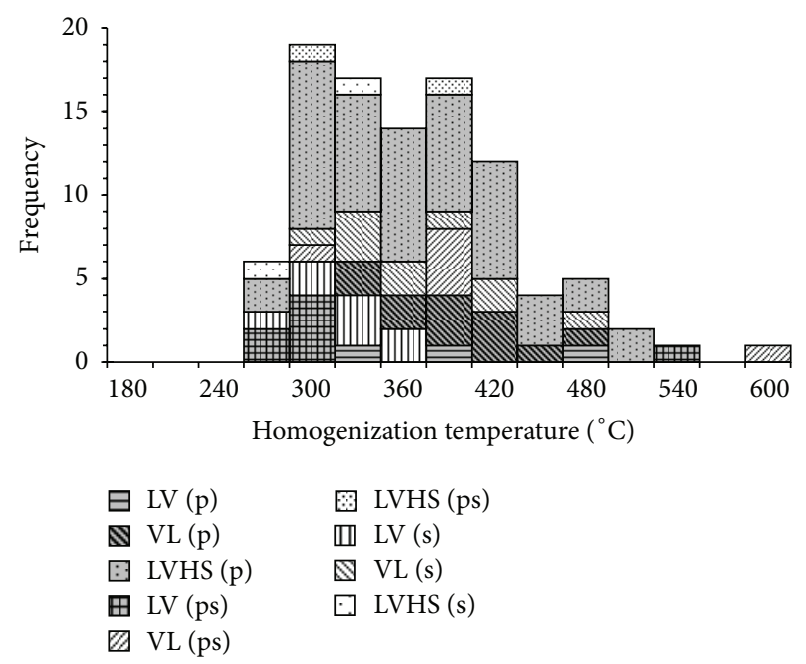

(b) Group II

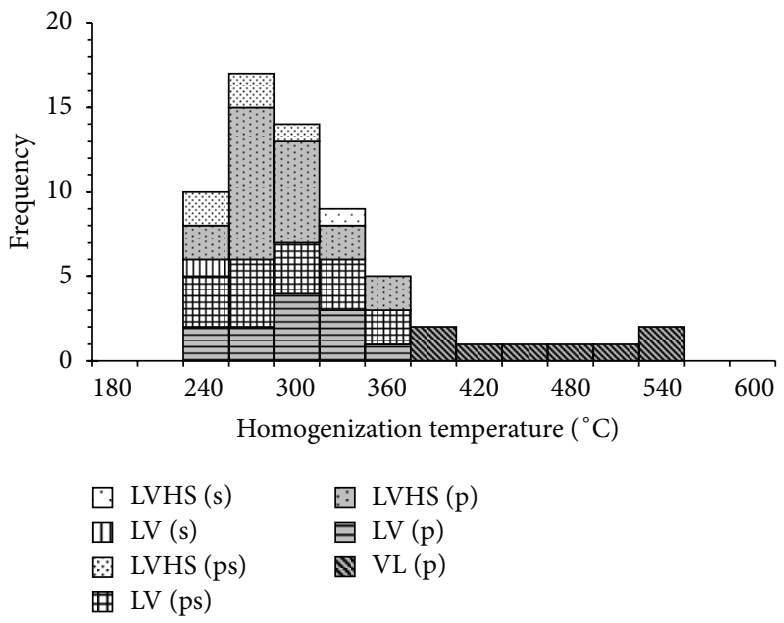

(c) Group III

FIGURE 4: Histograms of homogenization temperatures for LV, VL, and LVHS fluid inclusions from mineralized quartz veins (p: primary, ps: pseudosecondary, and s: secondary).

subtypes. Subtype $\mathrm{LVHS}_{1}$ inclusions are characterized by the presence of halite + chalcopyrite \pm anhydrite $\pm \mathrm{K}$-Fe$\mathrm{Cl}$ phase. Halite, anhydrite, and chalcopyrite have consistent phase ratios and are interpreted to be daughter minerals. Vapor bubbles occupy $<25 \%$ of the inclusions by volume. Subtype $\mathrm{LVHS}_{2}$ inclusions contain sylvite in addition to the phases in $\mathrm{LVHS}_{1}$ inclusions. The solid phases occupy $60 \%$ of inclusion volumes, and the vapor bubbles cccupy $20 \%$ of inclusion volumes. Subtype $\mathrm{LVHS}_{3}$ inclusions contain halite, which is commonly accompanied by hematite, but do not contain chalcopyrite, sylvite, or $\mathrm{K}-\mathrm{Fe}-\mathrm{Cl}$ phases. The volume of the solid phases is typically $<40 \%$ of the inclusions, and bubble volumes range between 20 and $60 \%$.

5.1. Microthermometric Analysis. The Linkam operating unit was applied to measure the temperatures of phase changes in fluid inclusions, which operates by passing preheated or precooled $\mathrm{N}_{2}$ vapor around the sample [20]. Stage calibration was performed using synthetic and/or well-known fluid inclusions. Accuracy at the standard reference temperatures was $\pm 0.2^{\circ} \mathrm{C}$ at $-56.6^{\circ} \mathrm{C}$ (triple point of $\mathrm{CO}_{2}$ ), $\pm 0.1^{\circ} \mathrm{C}$ at $0^{\circ} \mathrm{C}$ (melting point of ice), $\pm 2^{\circ} \mathrm{C}$ at $374.1^{\circ} \mathrm{C}$ (critical homogenization of $\mathrm{H}_{2} \mathrm{O}$ ), and $\pm 9^{\circ} \mathrm{C}$ at $573^{\circ} \mathrm{C}$ (alpha to beta quartz transition). The heating rate was approximately $1^{\circ} \mathrm{C} / \mathrm{min}$ near the temperatures of phase transitions. Descriptive statistics of microthermometric data in vein groups are shown in Table 1 .

5.2. Homogenization Temperatures. LV fluid inclusions homogenize to liquid $T_{\mathrm{h}}(\mathrm{L}+\mathrm{V} \rightarrow \mathrm{L})$ at temperatures between $215^{\circ}$ and $514^{\circ} \mathrm{C}$, with an average of $297^{\circ} \mathrm{C}$. Most of VL inclusions homogenize to vapor $T_{\mathrm{h}}(\mathrm{V}+\mathrm{L} \rightarrow \mathrm{V})$ between $287^{\circ}$ and $575^{\circ} \mathrm{C}$.

In the halite-bearing inclusions, $T_{\mathrm{s}} \mathrm{NaCl}$ (the temperature at which halite dissolves) and $T_{\mathrm{h}}(\mathrm{L}-\mathrm{V})$ (temperature of vapor and liquid homogenization) were recorded (Figure 4).

The liquid and vapour phases in LVHS inclusions homogenize to liquid at temperatures between $211^{\circ}$ and $487^{\circ} \mathrm{C}$. The liquid-vapour homogenization temperature for LVHS 
TABLE 1: Descriptive statistics of microthermometric data in vein groups at Darrehzar area.

\begin{tabular}{lccccc}
\hline $\begin{array}{l}\text { FI } \\
\text { type }\end{array}$ & Statistical parameter & $T_{\mathrm{h}}$ & $T_{\mathrm{S}} \mathrm{NaCL}$ & $\mathrm{L} / \mathrm{V}$ & Salinity \\
\hline \multirow{4}{*}{ LV } & Minimum & 215 & - & 1.2 & 2.01 \\
& Maximum & 514 & - & 19 & 16.32 \\
& Mean & 297 & - & 4.38 & 8.02 \\
& Standard deviation & 56.64 & - & 2.96 & 3.8 \\
\hline \multirow{4}{*}{ VL } & Minimum & 287 & - & 0.11 & 0.87 \\
& Maximum & 575 & - & 1 & 18.55 \\
& Mean & 421 & - & 0.49 & 9.36 \\
& Standard deviation & 67.83 & - & 0.3 & 5.2 \\
\hline \multirow{4}{*}{ LVHS } & Minimum & 211 & 211 & 0.47 & 31.44 \\
& Maximum & 487 & 510 & 9 & 59.86 \\
& Mean & 330 & 351 & 3.66 & 43.21 \\
& Standard deviation & 65.98 & 72.19 & 2 & 6.74 \\
\hline
\end{tabular}

inclusions is from $215^{\circ}$ to $350^{\circ} \mathrm{C}$ in quartz veins. The halite dissolution temperatures $\left(T_{\mathrm{s}} \mathrm{NaCl}\right)$ for LVHS inclusions are between $211^{\circ}$ and $510^{\circ} \mathrm{C}$. Anhydrite and chalcopyrite did not dissolve on heating to temperatures in excess of $600^{\circ} \mathrm{C}$. Chalcopyrite was identified on the basis of its optical characteristics (opacity and triangular cross-section) and composition in opened inclusions (SEM-EDAX analyses yielded peaks for $\mathrm{Cu}, \mathrm{Fe}$, and S). Anhydrite forms transparent anisotropic prisms and was shown by SEM-EDAX analyses to consist only of $\mathrm{Ca}$ and $\mathrm{S}$ (elements lighter than F could not be analyzed) [21].

5.3. Salinity in the Fluid Inclusions. Halite-bearing and nonhalite-bearing liquid-rich inclusions at Darrehzar exhibit a wide variation in salinity, ranging from 0.9 to $59.9 \mathrm{wt} \% \mathrm{NaCl}$ (Figure 5).

LVHS fluid inclusions (high-salinity population) have higher salinities than LV and VL inclusions (low-salinity population) and clearly separated each other by a salinity gap within the range of $19-31 \mathrm{wt} \%$ (Figure 5). Low-salinity inclusions have salinity from 0.9 to $18.6 \mathrm{wt} \% \mathrm{NaCl}$ and their correlation coefficient between the salinity and their homogenization temperature is weak $\left(R^{2}=0.07\right)$. Highsalinity inclusions have salinity between 31.4 and $59.9 \mathrm{wt} \%$ $\mathrm{NaCl}$ and have good correlation coefficient $\left(R^{2}=0.7\right)$ between the salinity and their homogenization temperature (Figure 6).

\section{Stable Isotope Investigation}

Samples containing veinlets of sulfides, quartz, and sulfates were selected for stable isotope analysis.

Oxygen isotope analyses were conducted on the samples of quartz veins in the potassic, transition, and phyllic alteration zones. Quartz grains were separated using both heavy liquid and hand picking methods.

Sulfide (pyrite, chalcopyrite, and molybdenite) and sulfate (anhydrite) samples were selected for sulfur isotopic

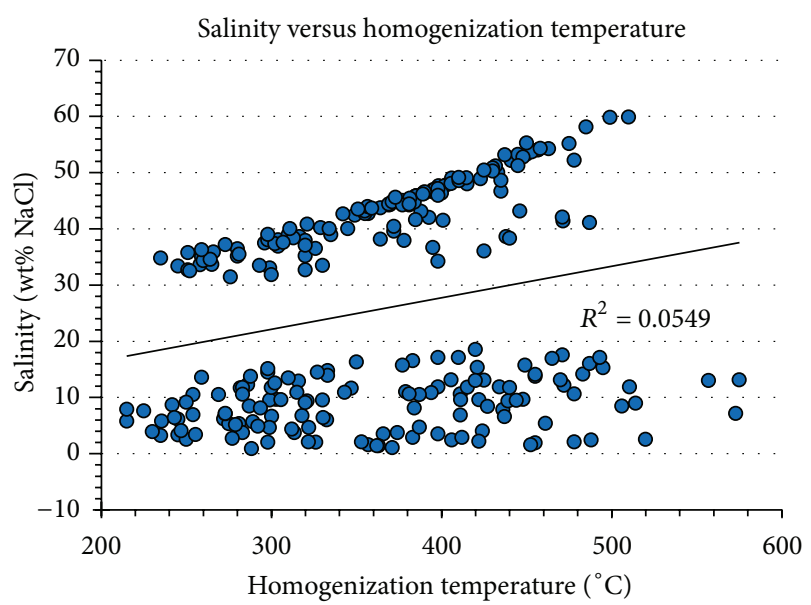

FIGURE 5: Scatter plot of salinity versus homogenization temperature showing two different populations.

analyses. These samples were prepared through crushing, sieving, and hand-picking. S, O isotope analyses were carried out in the laboratories at Centre for Stable Isotope Research and Analysis, University of Gottingen, Germany.

6.1. Oxygen Isotopes. The $\delta^{18} \mathrm{O}$ values of quartz are in range of $9 \%$ to 10.3 relative to standard mean ocean water (SMOW) with a mean of $9.6 \% . \delta^{18} \mathrm{O}_{\mathrm{H}_{2} \mathrm{O}}$ values were calculated from the quartz analyses using the fractionation equation of Matsuhisa et al. [24].

The range of $\delta^{18} \mathrm{O}_{\mathrm{H}_{2} \mathrm{O}}$ valuesis between $6.13 \%$ and $7.06 \%$ (Group I veins), $4.92 \%$ and 6.25\% (Group II veins), and 3.31\% and $4.22 \%$ (Group III veins) (Figure 7).

The result showed that hydrothermal fluids with deferent origin have circulated in three phases, responsible for fluid mineralization. In the first phase, orthomagmatic fluid $\left(\delta^{18} \mathrm{O}_{\text {(fluid) }} \delta>6 \%\right)$ was circulated at system and caused paragenic mineralization of quartz + k-feldspar + molybdenite + anhydrite \pm pyrite \pm chalcopyrite which formed Group I veins.

In the next phase by decreasing temperature and fluid cooling up to $350^{\circ} \mathrm{C}$, meteoric water flowed inward system $\left(\delta^{18} \mathrm{O}_{\text {(fluid) }} \sim 5 \%\right.$ to $\left.6 \%\right)$ and formed Group II veins consisting of quartz + chalcopyrite \pm pyrite \pm bornite \pm molybdenite. Phyllic alteration resulted from invasion of mixed meteoric waters with decreasing temperature of the system.

In the last phase, the hydrothermal system changed from magmatic to meteoric water and caused porphyry stock alteration $\left(\delta^{18} \mathrm{O}_{\text {(fluid) }}<4.5 \%\right)$. Based on fluid inclusion study and calculation of the isotopic composition of oreforming fluid with decreasing of temperature up to $300 \circ \mathrm{C}$, ore- forming fluid with properties close to the meteoric water caused paragenic mineralization of quartz + pyrite + calcite + chalcopyrite \pm anhydrite and made Group III veins.

6.2. Sulfur Isotopes. Sulfur isotopic analyses were performed on pyrite, anhydrite, chalcopyrite, and molybdenite samples separated from Groups I, II, and III veins. The eight pyrite samples analyzed have $\delta^{34} S$ values between $-3.1 \%$ and $-0.4 \%$, 


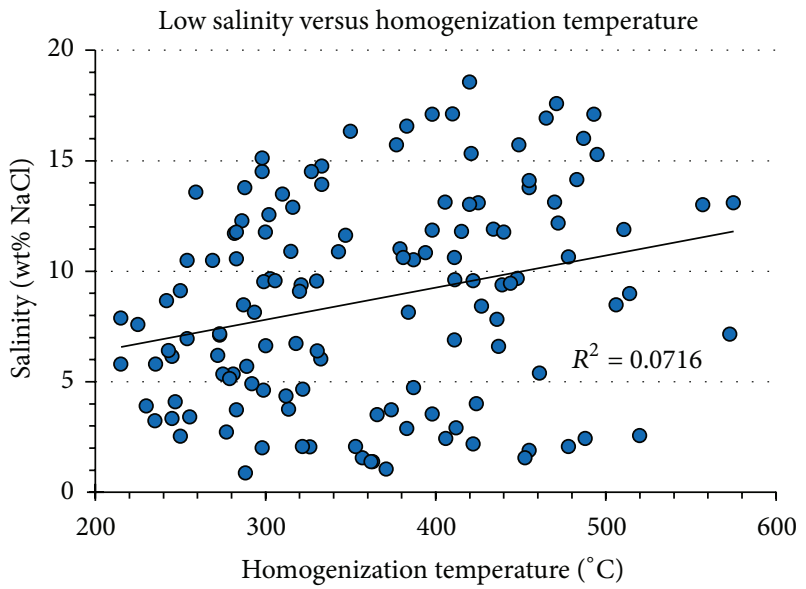

(a)

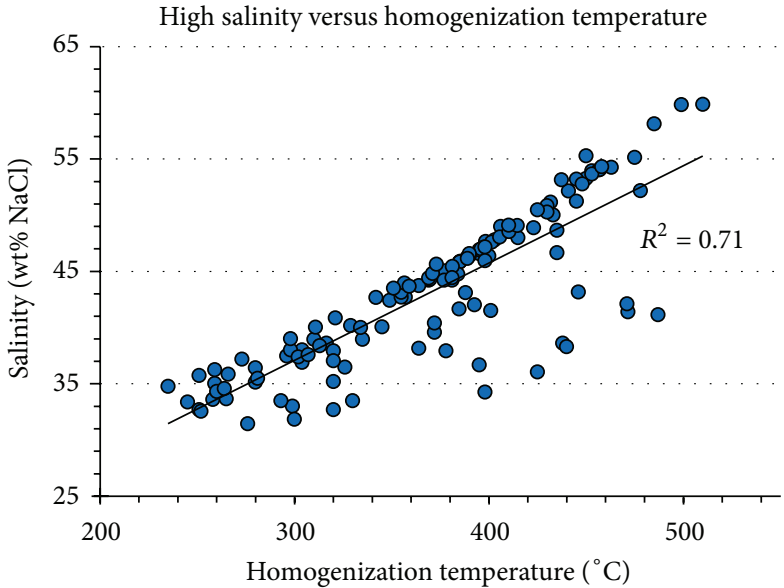

(b)

FIGURE 6: (a) Weak correlation coefficient between the salinity and their homogenization temperature in low-salinity population. (b) Good correlation coefficient between the salinity and their homogenization temperature in high-salinity inclusions.

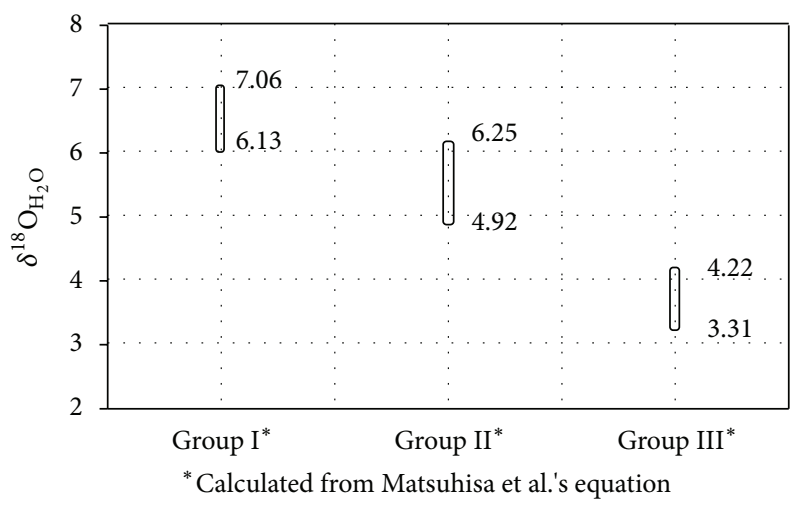

FIGURE 7: Oxygen isotope results of the mineralized group quartz veins.

the three chalcopyrite samples have $\delta^{34} \mathrm{~S}$ values of $-1.8 \%$ to $-1.3 \%$, the two molybdenite samples have $\delta^{34} \mathrm{~S}$ values ranging from $-1.8 \%$ to $-0.7 \%$, and the eleven anhydrite samples have $\delta^{34} \mathrm{~S}$ values from $10.3 \%$ to $11.7 \%$.

The $\delta^{34} \mathrm{~S}$ values of the anhydrite are approximately constant and heavier than those of associated or coexisting sulfides. One of two samples of molybdenite is enriched with $\delta^{34} S$ relative to pyrite and pyrite in turn is similarly enriched with $\delta^{34} S$ relative to chalcopyrite. These isotopic trends are consistent with isotope equilibrium theory and sulfur-isotope fractionation trends [25].

\section{Discussion}

The maximum pressure of fluid entrapment can be calculated from the estimated thickness of the overlying rock column at the time of intrusion. The latter represents $1500 \mathrm{~m}$ to $2000 \mathrm{~m}$ of volcanic, volcanic-clastic, and volcanic sedimentary complexes. This corresponds to a lithostatic pressure of 450 to
500 bars, assuming an average rock density of $2.7 \mathrm{~g} / \mathrm{cm}^{3}$ and a hydrostatic pressure of 150 to 200 bars, assuming a fluid density near $1 \mathrm{~g} / \mathrm{cm}^{3}$.

$\mathrm{LVHS}_{2}$ fluid inclusions occur with VL inclusions in Group I quartz veins associated with potassic alteration, defining fluid population I. The homogenization temperatures for type $\mathrm{LVHS}_{2}$ inclusions $\left(T_{\mathrm{h}}(\mathrm{L}-\mathrm{V})>T_{\mathrm{s}} \mathrm{NaCl}\right)$ vary between $330^{\circ}$ and $\sim 500^{\circ} \mathrm{C}$ and for coexisting VL inclusions vary between $400^{\circ}$ and $500^{\circ} \mathrm{C}$ (Figure 8).

At these temperatures, the maximum pressure for the coexistence of these two fluid inclusion types (bubble point curve) is approximately 300 to 400 bars. On the other hand, the existence of LVHS fluid inclusions with $T_{\mathrm{s}} \mathrm{NaCl}>T_{\mathrm{h}}(\mathrm{L}-$ $\mathrm{V})$ implies that pressure was locally or temporarily much higher. In fact, pressures estimated for those inclusions (fluid pressure) range up to 800 bars which is excessive lithostatic pressure (as already discussed, the lithostatic pressure was 450 to 500 bars) and that pressure generally oscillated between 150 to 200 bars (hydrostatic) and $>500$ bars in response to repeated cracking and sealing of the rock at $450^{\circ} \mathrm{C}$. So pressure during the trapping of fluid population I varied from 150-200 to $>500$ bars and temperature was $\sim 450^{\circ} \mathrm{C}$.

Fluid II is defined by the coexistence of $\mathrm{LVHS}_{3}$ and VL inclusions. In Groups I and II veins, $\mathrm{LVHS}_{3}$ inclusions homogenize by vapor disappearance after halite dissolution at a modal temperature of $350^{\circ} \mathrm{C}$. Based on data from Sourirajan and Kennedy [26] and Chou [27] for the NaCl$\mathrm{H}_{2} \mathrm{O}$ system, the corresponding fluid pressure was $\sim 200$ bars. VL inclusions homogenize to a vapor at between $380^{\circ}$ and $520^{\circ} \mathrm{C}$; that is, at significantly higher temperatures than $\mathrm{LVHS}_{3}$ inclusions, those of they could indicate heterogeneous entrapment of liquid and vapor during boiling. In Group III veins, the $\mathrm{LVHS}_{3}$ inclusions homogenize at temperatures $<300^{\circ} \mathrm{C}$ by both vapor disappearance and halite dissolution.

Fluid II was thus trapped at considerably lower temperatures than fluid $\mathrm{I}\left(350^{\circ}\right.$ versus $\left.350-500^{\circ} \mathrm{C}\right)$ and underwent 


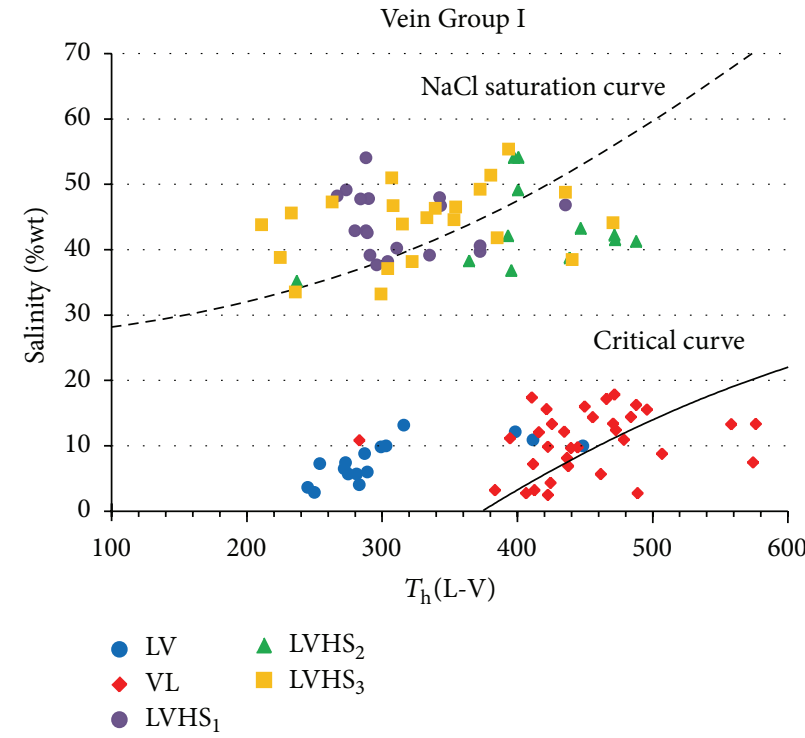

(a)

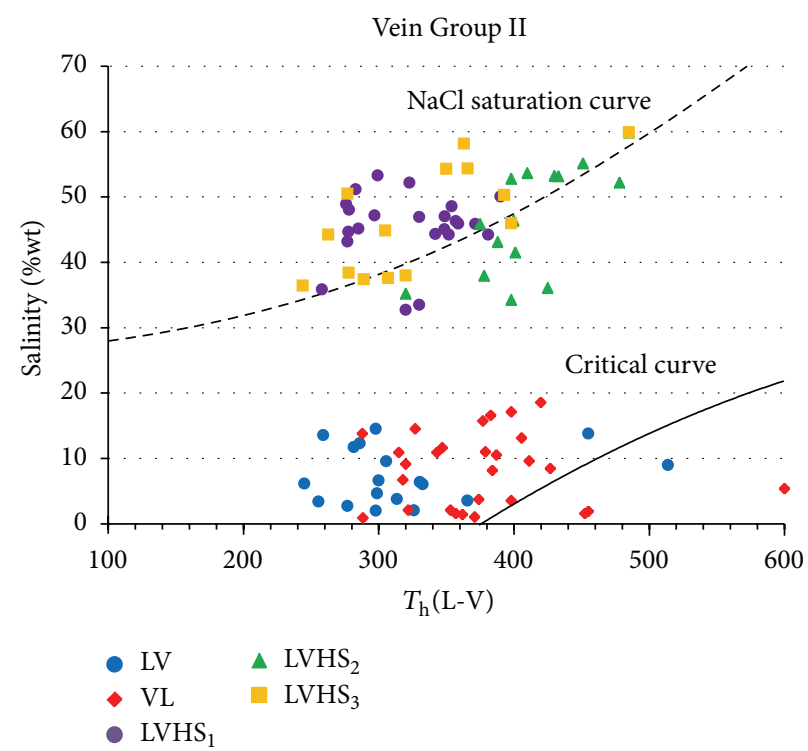

(b)

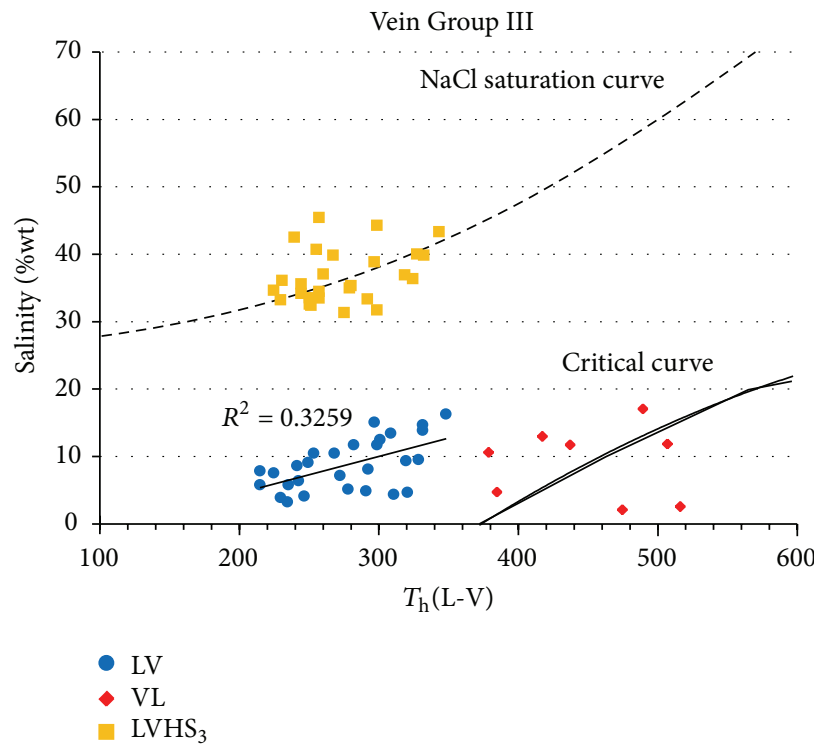

(c)

FIGURE 8: Liquid-vapour homogenization temperature versus salinity plotted on a section from the $\mathrm{NaCl}-\mathrm{H}_{2} \mathrm{O}$ system (halite saturation and critical curves from $[22,23])$.

cooling with the development of a progressively more open fracture system represented by Group III veins. The pressure was dominantly hydrostatic (150-200 bars).

Fluid III is defined by the existence of LV inclusions and represents a later fluid that circulated in the intrusion. These inclusions homogenize to liquid at temperatures between $240^{\circ}$ and $330^{\circ} \mathrm{C}$. Based on data of Chou [27], the minimum corresponding pressure is between 30 and150 bars.

7.1. Fluid Evolution. The high trapping temperatures and high salinity of LVHS 1 and LVHS 2 fluid inclusions suggest that Fluid population I probably represents an orthomagmatic fluid which is exsolved as a high-density phase from diorite-granodiorite magma and subsequently saturated with halite and boiled.

We propose that the source of Fluid II $\left(\mathrm{LVHS}_{3}\right.$ and VL fluid inclusions) was also mainly orthomagmatic (high salinity), but it circulated at lower temperature than Fluid I and mixed with an external fluid. This is also suggested by a trend from higher temperature and higher salinity to lower temperature and lower salinity for $\mathrm{LVHS}_{3}$ and LV fluid inclusions. Coexistence of $\mathrm{LVHS}_{3}$ fluid inclusions with VL fluid inclusions indicates that Fluid II boiled extensively. Fluid III was mainly meteoric water (low salinity), and it mixed to a great value with magmatic fluids (low temperature) (Figure 8). Also it circulated mainly in Group II and Group III veins. 


\section{Conclusions}

The multiple intrusions of microdiorite to diorite and granodiorite rocks at Darrehzar indicate a long-lived intrusive episode associated with repeated fracturing and hydrothermal activity. Fluid inclusion and isotopic analyses from the deposit indicate three distinct hydrothermal fluids. The first hydrothermal was characterized by high temperatures, high salinities, and $\delta^{18} \mathrm{O}_{\text {(fluid) }} \delta>6 \%$. The presence of molybdenite and anhydrite in Group I veins, chalcopyrite and anhydrite in Group II veins, and chalcopyrite and anhydrite in LVHS $_{1}$ and LVHS $_{2}$ inclusions from vein Groups I and II suggests that Fluid I was responsible for the transport and eventual deposition of $\mathrm{Fe}, \mathrm{Cu}, \mathrm{Mo}$, and S. Fluid population I could indicate an orthomagmatic fluid which is subsequently saturated with halite and boiled. The second hydrothermal fluid (Fluid II) was formed mainly by mixing magmatic fluid, at moderate-to-high temperature, and $\delta^{18} \mathrm{O}_{\text {(fluid) }} \delta \sim 5$ to $6 \%$. This fluid was responsible for sericitic alteration zones in the upper portion of the stock.

The third hydrothermal fluid (Fluid III) consisted of low temperature, low-to-moderate salinity, and $\delta^{18} \mathrm{O}_{\text {(fluid) }} \delta<$ $4.5 \%$. This fluid was responsible for peripheral propylitic alteration. The circulation of Fluid III, which did not penetrate into the hotter and most central part of the intrusion, caused this alteration zone. This fluid also caused some distribution of argillic alteration, in which almost all the feldspars were altered to kaolinite and other clay minerals.

These three interpreted hydrothermal fluids correspond to three different populations of fluid inclusions in Darrehzar veins.

Fluid III formed by progressive dilution of magmatic fluid with a great volume of meteoric waters. Incursion of dilute meteoric fluids into the permeable stockwork system increased $\mathrm{Na} / \mathrm{K}$ ratios and caused the remobilization redeposition of previously precipitated copper sulfides in fractured zones through acidification and oxidation.

\section{Conflict of Interests}

B. Alizadeh Sevari and A. Hezarkhani, as the authors of the paper, have no direct financial relation that might lead to a conflict of interests for any of them.

\section{References}

[1] C. W. Burnham, "Magmas and hydrothermal fluids," in Geochemistry of Hydrothermal Ore Deposits, H. L. Barnes, Ed., pp. 71-136, Jon Wiley \& Sons, 1979.

[2] T. Ulrich, D. Günther, and C. A. Heinrich, "The evolution of a porphyry $\mathrm{Cu}-\mathrm{Au}$ deposit, based on LA-ICP-MS analysis of fluid inclusions: bajo de la alumbrera, Argentina," Economic Geology, vol. 96, no. 8, pp. 1743-1774, 2001.

[3] R. H. Sillitoe, "Porphyry copper systems," Economic Geology, vol. 105, no. 1, pp. 3-41, 2010.

[4] R. H. Sillitoe, "Characteristics and controls of the largest porphyry copper-gold and epithermal gold deposits in the circum-pacific region," Australian Journal of Earth Sciences, vol. 44, no. 3, pp. 373-388, 1997.
[5] J. W. Hedenquist and J. P. Richards, "The influence of geochemical techniques on the development of genetic models for porphyry copper deposits," in Techniques in Hydrothermal Ore Deposits Geology, J. P. Richards and P. B. Larson, Eds., vol. 10, pp. 235-256, 1998.

[6] J. Stocklin and A. Setudenia, Lexique Stratigraphique International, vol. 3, ASIE, Centre National de la Recherche Scientifique, Quai Anatole, France, 1972.

[7] J. O. Stocklin, Structural Correlation of the Alpine Ranges Between Iran and Central Asia, Mémoire Hors Série, Société Géologique de France, Paris, France, 1977.

[8] M. Berberian, "An explanatory note on the first seismotectonic map of Iran, a seismotectonic review of the country," Report 39, In Geological Survey of Iran, pp.7-142, 1976.

[9] M. Berberian, "The southern caspian: a compressional depression floored by a trapped, modified oceanic crust," Canadian Journal of Earth Sciences, vol. 20, no. 2, pp. 163-183, 1983.

[10] M. Berberian and G. C. King, "Towards a paleogeography and tectonic evolution of Iran," Canadian Journal of Earth Sciences, vol. 18, no. 2, pp. 210-265, 1981.

[11] F. Pourhosseini, Petrogenesis of Iranian Plutons: A Study of the Natanz and Bazman Intrusive Complexes [Ph.D. thesis], University of Cambridge, 1981.

[12] R. Derakhshani and M. Abdolzadeh, "Geochemistry, mineralization and alteration zones of darrehzar porphyry copper deposit, Kerman, Iran," Journal of Applied Sciences, vol. 9, no. 9, pp. 1628-1646, 2009.

[13] B. Grujicic and S. Volickovic, "Copper Deposit darrehzar mineral inventories computation," Internal Report 27, National Iranian Copper Industries, Exploration Department, 1991.

[14] M. Maanijou, Alteration halos and their connection to mineralization of darrehzar porphyry $\mathrm{Cu}$ deposit and its geochemical zoning, Pariz area, Kerman, Iran [M.S. thesis], Shahid Beheshti University, Tehran, Iran, 1993.

[15] H. Ranjbar, H. Hassanzadeh, M. Torabi, and O. Ilaghi, "Integration and analysis of airborne geophysical data of the Darrehzar Area, Kerman Province, Iran, using principal component analysis," Journal of Applied Geophysics, vol. 48, no. 1, pp. 33-41, 2001.

[16] H. Etminan, "Etminan The discovery of porphyry coppermolybdenum mineralization adjacent to Sungun village in the northwest of Ahar and a proposed program for its detailed exploration," Confidential Report, Iran, Geological Report, Geological Survey of Iran, 1977.

[17] J. Shahabpour, Aspects of alteration and mineralization at the Sar-Cheshmeh copper-molybdenum deposit, Kerman, Iran [Ph.D. thesis], Leeds University, 1982.

[18] A. Hezarkhani, "Hydrothermal evolution of the sar-cheshmeh porphyry $\mathrm{Cu}-\mathrm{Mo}$ deposit, Iran: evidence from fluid inclusions," Journal of Asian Earth Sciences, vol. 28, no. 4-6, pp. 409-422, 2006.

[19] L. B. Gustafson and J. P. Hunt, “The porphyry copper deposit at El Salvador, Chile," Economic Geology, vol. 70, no. 5, pp. 857-912, 1975.

[20] J. Were, R. J. Bodnar, and P. B. Barton, "A novel gas-flow fluid inclusion heating-freezing stage," Geological Society of America, Abstracts and Programs 11, 539, 1979.

[21] A. Hezarkhani, A. E. Williams-Jones, and C. H. Gammons, "Factors controlling copper solubility and chalcopyrite deposition in the Sungun porphyry copper deposit, Iran," Mineralium Deposita, vol. 34, no. 8, pp. 770-783, 1999. 
[22] R. J. Bodnar, "Introduction to aqueous fluid systems," in Fluid Inclusions: Analysis and Interpretation, I. Samson, A. Anderson, and D. Marshall, Eds., pp. 81-99, Mineralogical Association of Canada, Quebec, Canada, 2003.

[23] E. Roedder, "Introduction to fluid inclusions," Reviews in Mineralogy, vol. 12, p. 644, 1984.

[24] Y. Matsuhisa, J. R. Goldsmith, and R. N. Clayton, "Oxygen isotopic fractionation in the system quartz-albite-anorthitewater," Geochimica et Cosmochimica Acta, vol. 43, no. 7, pp. 11311140, 1979.

[25] H. Ohmoto and M. B. Goldhaber, "Sulfur and carbon isotopes," in Geochemistry of Hydrothermal Ore Deposits, H. L. Barnes, Ed., pp. 517-611, John Wiley and Sons, New York, NY,USA, 1997.

[26] S. Sourirajan and G. C. Kennedy, "The system $\mathrm{H}_{2} \mathrm{O}-\mathrm{NaCl}$ at elevated temperatures and pressures," The American Journal of Science, no. 260, pp. 115-141, 1962.

[27] I.-M. Chou, "Phase relations in the system NaCl-KCl- $\mathrm{H}_{2} \mathrm{O}$. III: solubilities of halite in vapor-saturated liquids above $445^{\circ} \mathrm{C}$ and redetermination of phase equilibrium properties in the system NaCl- $\mathrm{H}_{2} \mathrm{O}$ to $1000^{\circ} \mathrm{C}$ and 1500 bars," Geochimica et Cosmochimica Acta, vol. 51, no. 7, pp. 1965-1975, 1987. 

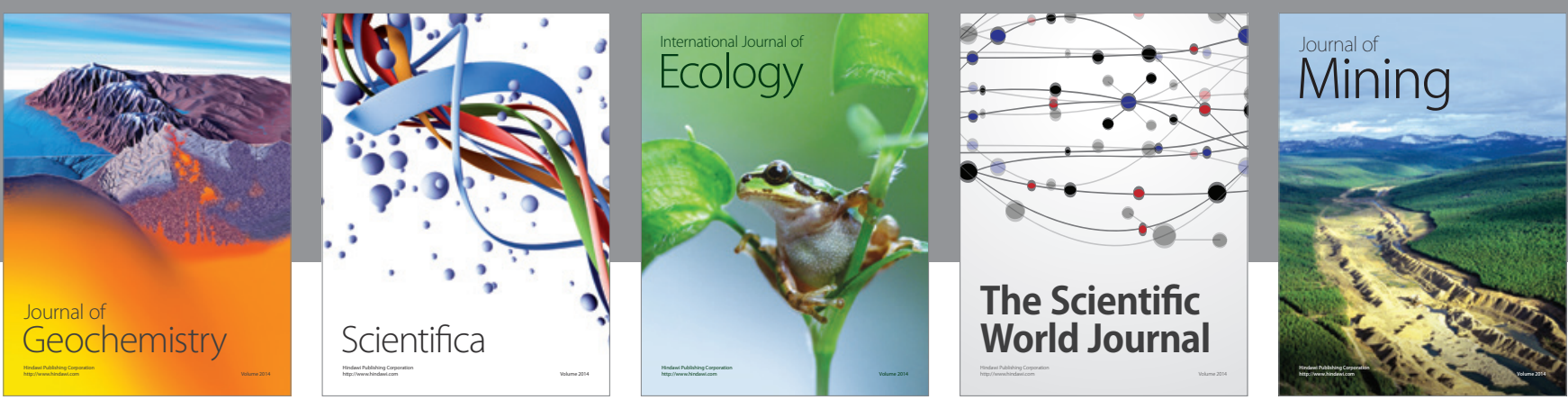

The Scientific World Journal
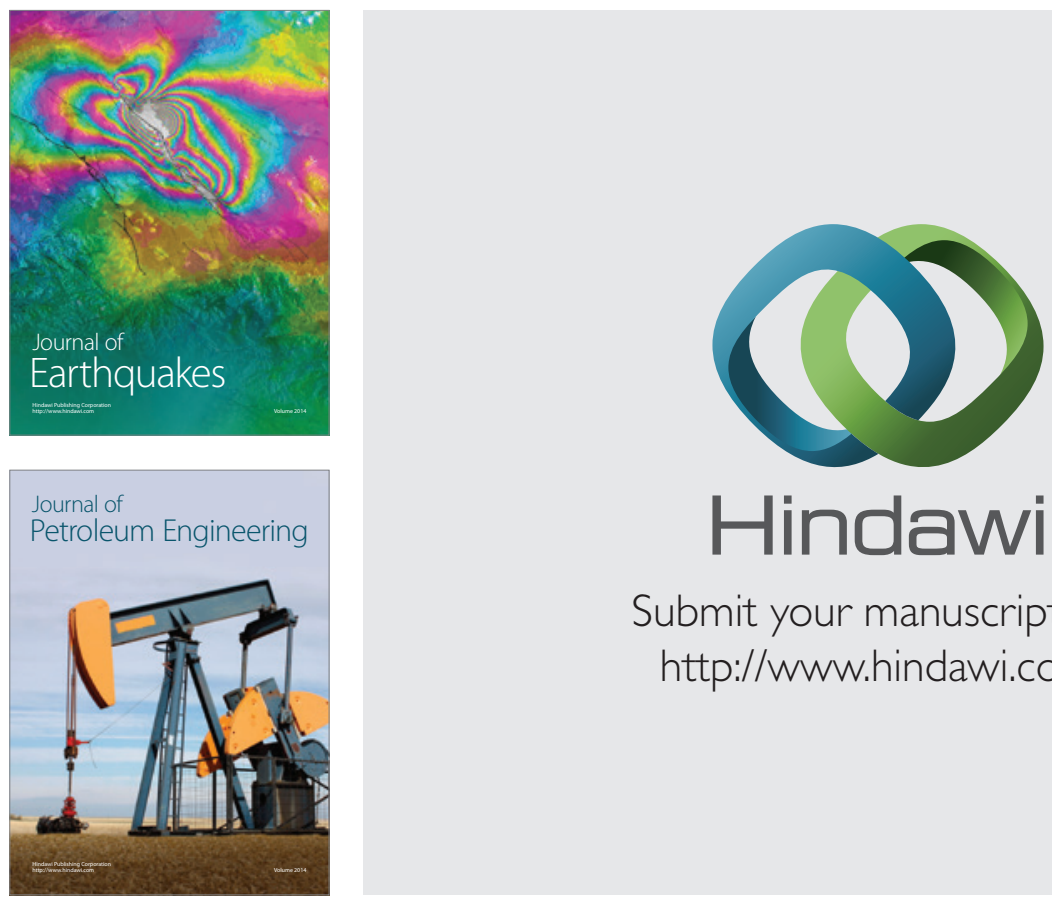

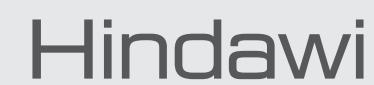

Submit your manuscripts at

http://www.hindawi.com
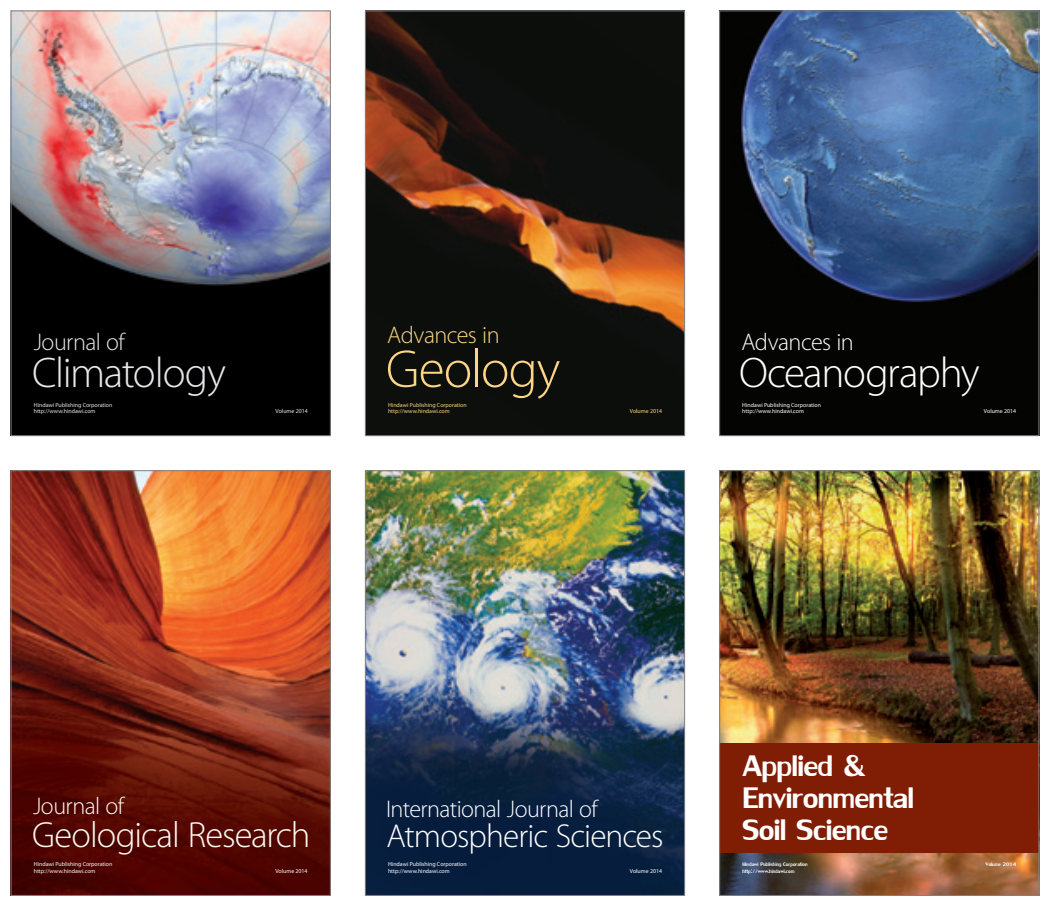
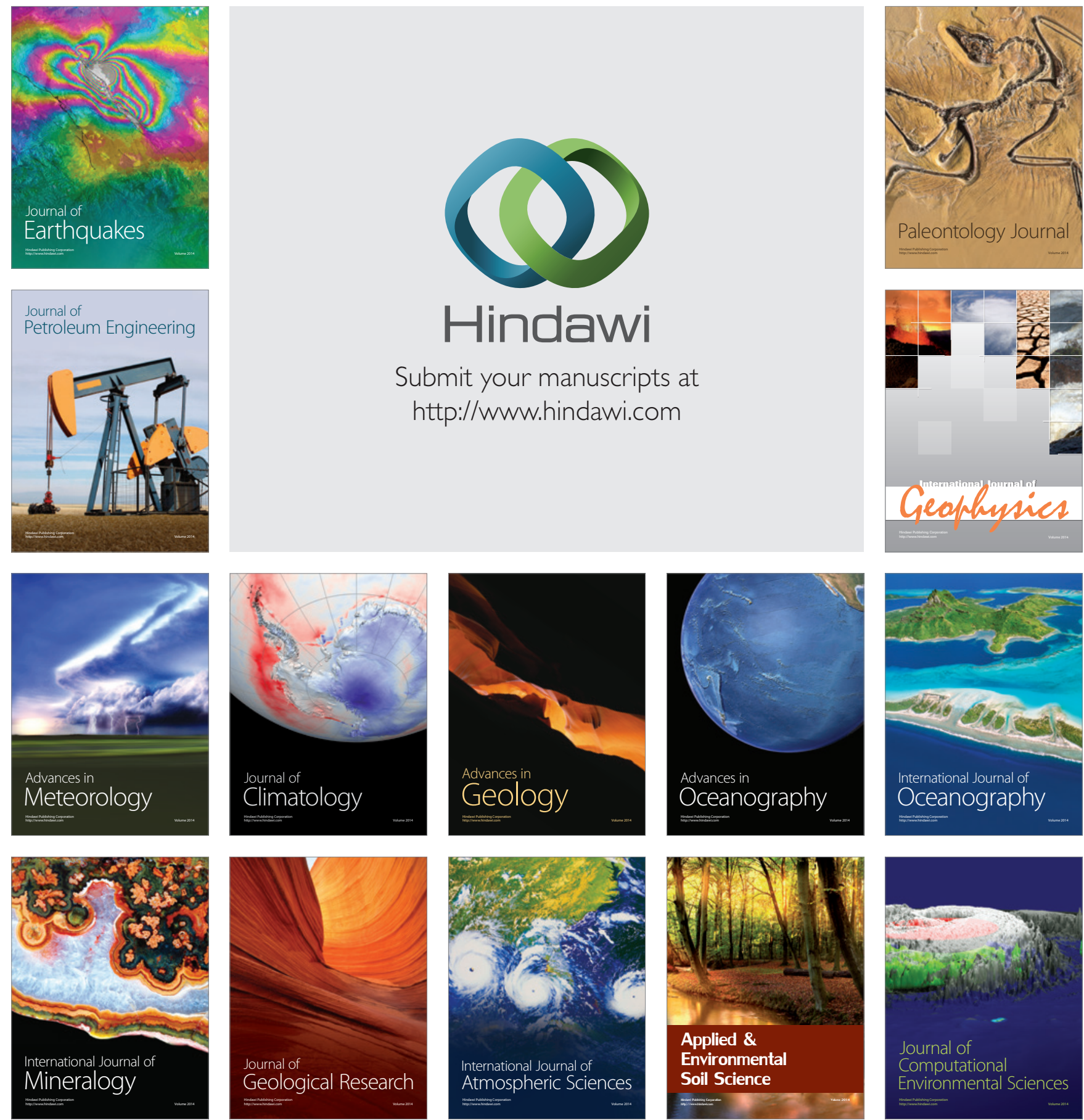